doi: $10.2478 / v 10221-011-0020-5$

\title{
Theoretical shortcomings of the Grossman model
}

\section{Teoretične omejitve Grossmanovega modela}

\author{
Rok Hren ${ }^{1}$ \\ ${ }^{1}$ Johnson \& Johnson, d.o.o., Šmartinska 53, 1000 Ljubljana, Slovenia \\ e-mail: rhren@its.jnj.com
}

pregledni znanstveni članek

UDK: 614

članek prispel: 5. 10. 2011; članek sprejet: 30. 1. 2012

citirajte članek kot / cite this article as:

Bilt - Ekon Organ Inform Zdrav 2012; 28(1): 63-75

\begin{abstract}
This article contains a review of the seminal Grossman model from a perspective of assumptions and simplifications, which were necessary to make the model tractable. The Grossman model emphasises health as a fundamental commodity, which implies that the demand for healthcare is a derived demand; in the model, individuals are both consumers and producers of health. The model predicts that an individual would invest in health until the marginal benefit of health equals its marginal cost; this equilibrium demand for health entails that the length of an individual's life would be determined endogenously. This review also discusses the model's refinements and extensions that have relaxed some of the constraints of the original model. In spite of its shortcomings, the Grossman model remains - even after 40 years - one of the few models in the realm of health economics, which attempts to conceptualise the complex demand for health and healthcare both theoretically and empirically.
\end{abstract}

Key words: health, demand for health, model, health economics, health production

\section{Izvleček}

Članek pregledno predstavlja privzetke in poenostavitve Grossmanovega modela, ki so potrebni, da bi bil model rešljiv. Grossmanov model opredeljuje 
zdravje kot temeljno dobrino, kar pomeni, da je povpraševanje po zdravstveni oskrbi izpeljano povpraševanje; v modelu so posamezniki tako "potrošniki« kot "proizvajalci zdravja «. Model napoveduje, da bo posameznik tako dolgo vlagal v svoje zdravje, dokler marginalna korist zdravja ne bo enaka marginalnim stroškom zdravja; to ravnovesno povpraševanje po zdravju tako endogeno določa trajanje posameznikovega življenja. Ta pregled obravnava tudi dopolnitve in razširitve modela, ki sproščajo nekatere omejitve prvotnega modela. Kljub pomanjkljivostim je Grossmanov model - celo po 40 letih - eden redkih modelov na področju ekonomije zdravja, ki tako teoretično kot tudi empirično poskuša konceptualizirati kompleksno zahtevo po zdravju in zdravstvenem varstvu.

Ključne besede: zdravje, povpraševanje po zdravju, model, zdravstvena ekonomija, produkcija zdravja

\section{Introduction}

Health of an individual is an elusive term and has received - due to its importance - considerable attention resulting in a spectrum of definitions: one of the starting points is an ideological declaration in the World Health Organization charter recognising health as 'a state of complete, physical and mental well-being, and not merely the absence of disease or infirmity' (1). Among the determinants of health, the quality of health systems is often cited as the critical one in promoting, restoring or maintaining health (2); although nowadays it is well accepted that health consists of a complex array of determinants (e.g. material circumstances, behaviours, biological factors, psychosocial factors) (3). A good case in point is the qualitative difference between the epidemiological transition in Western and Eastern European countries, with the latter missing the 'cardiovascular revolution' (4) or entering it with much delay $(5,6)$. Casselli et al. (7) attributed this divergence to the centralised and administrative modus operandi of healthcare systems within the communist regimes; while the 'revolution' fundamentally depends on the individual's initiative and on modifying one's own personal behaviour towards their health. The concept and knowledge of health (both at the individual and population level) reaches well beyond the academic interest and has practical goals in, among other things, setting and evaluating the public health policies, establishing priorities in providing health services, and is important for detecting inequalities. As these endpoints have been highly relevant for society, there has been a need, historically, to develop an econometric model of demand for health. Forty years ago, Michael Grossman created a model of health as a durable capital (8) and this seminal model (8-10) builds on an intuitive notion that health has many inputs. Furthermore, the model of Grossman is founded on an important concept of health as a fundamental commodity, which implies that demand for health 
supersedes the demand for healthcare, thereby making the demand for healthcare a derived demand. Following the framework of the household production theory (11), the Grossman model argues that health is both consumption and an investment commodity, which means that individuals are both consumers and producers of health. Although the model has received some severe criticism since its inception (see e.g. 12, 13), it is unique in its approach within a realm of health economics to both theoretically and empirically conceptualise a complex demand for health. The Grossman model remains influential, and to better understand the implications of its central role during the past 40 years we will attempt to highlight some of its theoretical shortcomings in this review.

The paper is organised as follows: in Section 2, the Grossman model is summarised; the analysis of theoretical shortcomings in Section 3 is divided into three parts, with two major abstractions presented first; in Section 4, the theoretical shortcomings of the model are discussed from the overall perspective of health economics, and the conclusion points are provided in Section 5.

\section{An overview of the model}

In the model, the health of an individual is treated as a durable and endogenouslydetermined capital 'stock' (14), which evolves over time, obeying the following equation,

$H_{t+1}-H_{t}=I_{t}-\delta_{t} H t$

where $H_{t+1}$ is the health capital at the beginning of an interval, $t+1, I_{t}$ is the gross investment during the interval $t$, and $\delta_{t}$ is the rate of depreciation that is assumed constant within a given time interval $t$, and exogenously dependent only on an individual's age. The boundary conditions for Eq. (1) are the initial health capital $H(t=0)=H_{0}$ and the minimum health capital required for the individual to exist, $H_{\text {min }}$; terminal time $t^{*}$ is determined endogenously when $H\left(t^{*}\right) \leq H_{\min }$.

As health capital cannot be traded, gross investment into health $I_{t}$ has to be nonnegative. In the model, it is produced by combining two inputs - medical care $M_{t}$ and an individual's time input $\mathrm{TH}_{t}$ - and affected by the efficiency parameter $E_{t}$ defined in terms of the level of education, i.e.

$I_{t}=I\left(M_{t} T H_{t} ; E_{t}\right)$.

Furthermore, the production of gross investment is assumed to be linear and homogeneous in $M_{t}$ and $T_{t^{\prime}}$ thereby implying constant returns to scale. As is obvious from Eq. (1b), Grossman 'has abstracted away the effects of all other market goods, for example, cigarette smoking, diet and housing, upon health' (15). An output of health capital is healthy days, which have a concave and increasing production function in health stock (8), i.e.

$h_{t}=\Phi\left(H_{t}\right): \Phi^{\prime}\left(H_{t}\right)>0, \Phi^{\prime \prime}\left(H_{t}\right)>0$. 
As noted by McGuire et al. (15), $\Phi^{\prime}\left(H_{t}\right)$ 'may be considered as the marginal product of the stock of health in healthy days'. The concavity of the production function implies that people with worse health would benefit more from the improvement in health stock than healthier people.

Formally, the Grossman model is based on the maximisation of an intertemporal utility over an individual's lifetime. The utility is a function of healthy days $h_{t}$ and a consumption of a composite commodity other than health $Z_{t}(8)$,

$U=U\left(h_{\alpha}, \ldots, h_{n^{\prime}} ; z_{\sigma^{\prime}} \ldots, Z_{n}\right)$,

where $n$ is the length of life, which in the model - as we have shown above - is endogenously determined. Similarly to the gross investment in health Eq. (1b), the total consumption of the composite commodity $Z_{t}$ also obeys the household production function (8),

$Z_{t}=I\left(X_{t^{\prime}} T_{t^{\prime}} E_{t}\right)$,

where $X_{t}$ is the market good input, $T_{t}$ equals time spent in producing $Z$, and $E_{t}$ is - as in Eq. (1b) - an efficiency parameter (education).

The full wealth constraint is defined in the Grossman model as (8)

$\sum_{t=0}^{n}\left[P_{t} M_{t}+Q_{t} X_{t}+W_{t}\left(T L_{t}+T H_{t}+T_{t}\right)\right] \frac{1}{(1+r)^{t}}=A_{0}+\sum_{t=0}^{n} W_{t} \Omega \frac{1}{(1+r)^{t}}$

where $P_{t}$ is the price of medical care, $M_{t^{\prime}} Q_{t}$ is the price of market goods $X_{t^{\prime}} W_{t}$ is the wage rate, $T L_{t}$ is sick time, while $T H_{t}$ and $T_{t}$ is time spent on producing health and market goods respectively; $r$ is the opportunity cost of capital, $A_{o}$ is the discounted value of capital income, and $\Omega$ is the total amount of time available. Grossman emphasised in his paper (8) that 'full wealth equals initial assets plus the present value of the earnings an individual would obtain if he spent all of his time at work' and thus explicitly assigned value to non-work time.

Healthy days can therefore be used - in addition to investing into health as above -for increasing an individual's income (investment good) or increasing an individual's utility (consumption good), as health capital has positive influence on both income and utility. It is the objective of an individual to seek the optimal path of health capital through their life cycle by weighing the benefits above versus the opportunity costs of investment in health. It can be shown that by maximising an individual's intertemporal utility function Eq. (1d) subject to restrictions Eqs. (1a and $1 \mathrm{f}$ ), while taking into account Eqs. (1b, $1 \mathrm{c}$ and $1 \mathrm{e}$ ), the equilibrium condition for health capital during an interval $t$ is determined by $(8,16)$,

$p_{t}+n_{t}=\left\{r+\delta_{t}-\pi_{t-1}^{\prime}\right\} \pi t_{-1}$

where $p_{t}$ and $n_{t}$ are pecuniary and non-pecuniary marginal benefits of health capital respectively,

$p_{t}=\Phi^{\prime}{ }_{t} W_{t^{\prime}}$ 
$n_{t}=\frac{\Phi_{t}^{\prime} U_{\phi t}(1+r)^{t}}{\lambda}$

is the marginal utility of health time, $\lambda$ is the marginal utility of wealth, $\Phi_{t}^{\prime}$ is the marginal product of health in terms of healthy days, $r$ is the interest rate, $\pi_{t-1}$ is the marginal cost of investment in health at an interval $t-1$, and $\pi_{t-1}^{\prime}$ is its relative rate of change between intervals $t-1$ and $t$. Due to constant returns to scale, $\pi_{t-1}$ does not depend on health capital and is thus exogenous; Grossman (8) further assumed $\pi_{t-1}$ to be constant through the life-cycle and thus $\pi_{t-1}^{\prime}$ equals zero.

Often, Eq. (2) is divided into two sub-models by setting, in turn, one of the two terms on the left side to zero. When for example, non-pecuniary benefit is zero due to an individual not gaining any utility from healthy days, we talk about an 'investment' sub-model, as the left side is really a return of investment in health (equalling wage rate multiplied by the marginal product of health capital). Such a dichotomy is convenient although it may also give an erroneous impression of the two rivalling hypotheses, each attempting to uncover potentially the 'true' nature of demand for health (17).

\section{An analysis of the model's theoretical shortcomings}

The major shortcomings of the model are related to its complete neglection of two aspects which may likely affect demand for health: uncertainty and imperfect information. McGuire et al (15) eloquently summarised the latter issue by noting that an individual is 'short of the necessary information to form a judgement about the most preferred health state at which to aim.' But let us first tackle the model's certainty.

\subsection{Certainty}

The model is deterministic, and as such does not take into account the often observed random occurrences of illnesses, or 'stochastic shocks' (12). The rate of deterioration of $\delta_{t}$ is exogenous and deterministic, although the model allows it to change from one interval to another; in fact, it can easily be shown within the investment sub-model that the constant deterioration rate $\delta_{t}=\delta_{t-1}$, would actually lead to constant health capital, attaining an individual eternal life (8). The model, on the other hand, cannot cope with sudden and rapid increases in $\delta_{t^{\prime}}$ which may worsen the health capital within an interval $t$ to such a degree that health investment may be insufficient to recover optimal health capital determined by Eq. (2). Such a gap between the actual and optimal health capital may undermine the applicability of the model. 
The planning horizon of the model amounts to at least two time intervals (Eqs. 1a and 2), although for the model to have predictive power, the corresponding planning horizon should run for several years, preferably a life time. As noted by Zweifel and Breyer (12), the planning horizon may, in the presence of life-threatening conditions, shrink to 'a few days or even hours'. Thereby, the optimal path of health capital defined by Eq. (2) and derived from intertemporal optimisation of an individual's utility function, may either (i) become somewhat irrelevant, or (ii) may necessitate shrinking the time interval $t$ of the model accordingly, which may in turn diminish the model's predictive value.

While in the original model the rate of deterioration $\delta_{t}$ depends only on age, it may be -from a theoretical point of view at least-adapted to include lifestyle influences (18). The level of certainty of the model is clearly overstated and to remedy this drawback, Grossman (8) proposed to assign the probability distribution of $\delta_{t}$ for a given time interval. Both approaches can be criticised as 'mechanistic' for not intrinsically taking into account the stochastic nature of health/illness by including variables in the gross investment, such as: diet, exercise, smoking (19); though this would be challenging for the model due to the introduction of joint production (15). McGuire et al. (15) further argued that assigning probabilities models the risk, but not the inherent uncertainty.

Liljas (20) extended the model by making the depreciation rate health-dependant, i.e. $\delta_{t}\left(H_{t}\right)$, and found that - when health capital is high - the optimal health capital would be larger than that found when using an exogenously-determined depreciation rate $\delta_{t^{\prime}}$ but would be smaller when the health capital is low.

\subsection{Perfect information flow}

In the model, an individual is sovereign and has complete information and perfect knowledge regarding their health capital, marginal benefits of current and future investment into health, current and future health depreciation rate and interest rate, and complete insight into the health production process, particularly with respect to the income elasticity of substitution between healthcare and an individual's time input. McGuire et al. (15) argued that such an abstraction is unrealistic as it evades uncertainty connected to the stochastic nature of disease occurrence and the unpredictability of future healthcare costs (which very much depend on future technology). Zweifel and Breyer (12) noted that 'health status is governed by the stochastic process' and that an individual can at best 'influence probabilities of transition from one state to another'.

The model assumes individuals being rational in strictly following Eq. (2): for example, when the rate of depreciation $\delta_{t}$ increases with age, the opportunity cost of health capital increases, and consequently, an individual chooses to increase the marginal benefits from health by decreasing the demand for health. Health capital in general, and 'death' stock $H_{\min }$ in particular, are thus endogenous, rational 
choices of an individual rather than imminent outcomes of exogenous, stochastic shocks, with an individual having full control over their time of death.

Assumption of perfect information in the model also abstracts away from the agency relationship; conceptually, it is rather difficult to model a demand for health and healthcare while neglecting major decision-makers in the healthcare sector - physicians. As pointed out by McGuire et al. (15), a principal-patient may certainly require information from their agent-physician, and may also to various degrees relinquish decision-making powers to them.

\subsection{Other shortcomings related to the model's assumptions}

The model rests on a number of assumptions, which can be relaxed in some cases; here, we list the major ones, with some proposals that refine the model.

\section{Gross investment function}

The model assumes that health investment is produced under constant returnsto-scale conditions, which means that it is neglecting the well-known declining productivity of medical care (21). Along with some other improvements, Ehrlich and Chuma (22) incorporated the diminishing returns-to-scale gross investment function into their extension of the model. Grossman (10) retorted that diminishing returns-to-scale 'greatly complicates the model because the marginal cost of gross investment and its percentage rate of change over time become endogenous variables that depend on the quantity of investment and its rate of change'; a similar view was earlier shared by Usher (23).

Another important assumption, following directly from Eq. (1a), is a continuous investment into health to ensure the steady flow of healthy days; healthcare is thereby desired solely as an investment in health and not as a means to recover health capital. This is a rather crude abstraction of demand for healthcare, which is most often reactive due to illness or accident, and for that reason stochastic and discontinuous in its nature; the steady demand for preventive healthcare can safely be assumed to be small compared to these random 'spikes', when most of the time healthcare consumption and production also occur concurrently. There are additional complications arising from uncertain healthcare outcomes and the fact that healthcare is a heterogeneous commodity (15).

\section{Absence of health insurance}

The model operates in a world without health insurance and assumes that all healthcare costs are covered either from income or personal wealth. This assumption logically arises from another assumption - that of the continuous investment in health under conditions of perfect information, which means that an individual is purchasing healthcare like any other commodity. However, due to the unpredictability of illness and the corresponding healthcare costs, in a risk-averse individual the demand for healthcare is fundamentally linked to the demand for healthcare insurance, at the very least. Including healthcare insurance 
in the gross investment function would of course severely complicate the analytics of the model.

\section{The 'dual nature' of health capital benefits}

The two sub-models are more the result of analytical convenience than competing hypotheses; Muurien (17) noted that an individual has both consumption and investment motive to demand health; she concluded that sub-models complement, rather than substitute each other, and that pure sub-models represent extreme cases. Halliday et al. (24) argued that with age the consumption motive for health investment is progressively gaining in importance, while the investment motive should be dominant for the young and healthy.

An interesting conceptual extension of the pure 'consumption' sub-model was carried out by Cropper (25), who assumed that by investing in health, an individual is avoiding disutility due to illness rather than loss of income due to sick days; she considered illness and death as temporary and permanent disruptions of an individual's utility stream.

\section{Uniqueness of health capital}

Muurien (17) also argued that all three fundamental types of capital i.e. health capital, human capital (education) and financial capital (25) produce a flow of healthy days and are to some degree interchangeable. In our view, health capital retains its unique and fundamental role, as it is a pre-requisite for the very existence of an individual-organism.

\section{Instantaneous adjustment to optimal level}

The model rests on the assumption that the health capital adjusts instantaneously to its desired/optimal level, defined by Eq. (2). Wagstaff (16) revised the model by allowing the partial adjustment of health capital within each interval $t$.

\section{Transversality condition}

Ehrlich and Chuma (22) criticised the model that it 'does not develop the required terminal (transversality) conditions', to which Grossman (10) responded by defining the length of life iteratively via terminal conditions for health as $H_{t}>H_{\min }$ and $H_{t+1} \leq H_{\text {min }}$.

\section{Discrete time steps}

The empirical model would anyhow demand discretisation. The disadvantage in this is that, from a theoretical point of view, the health capital is held constant during a given time interval $t$ (e.g. for a year). As discussed above, an individual's health capital may deteriorate rapidly within a time interval, due to unforeseen stochastic shocks.

Another assumption related to discretisation is the intertemporal separability of the utility function due to its form $U=\sum m_{t} u_{t^{\prime}}$, where $u_{t}$ is the utility in an interval $t$, and $m_{t}$ is the rate of time preference of an individual (27). This separability simplifies the solutions for the optimisation of the utility function (28). 


\section{An individual as an isolated health producer}

The model considers an individual as an isolated health producer, which neglects the fact that most individuals spend their lives with other individuals (i.e. within families), who may influence each other's behaviours. Jacobson (29) and Bolin et al. (30) took into account this notion and modelled the family as a health producing unit and spouses as Nash-bargainers.

\section{Binary health states}

The model simplifies the complexity of an individual's health status into binary states ('sick' or 'healthy'); more realistic approximation can be introduced by a continuum of health states (20).

\section{Exogenous variables}

In the model, wage is exogenously determined and assumed constant through the life-cycle in its original version. It is likely that ill health would not only negatively affect the number of healthy days, and hence the number of working days, but would also affect the wages. This would again complicate the analytics of the model.

The level of education is exogenously determined and enters gross investment function Eq. (1b) and house production function (1) as an efficiency parameter. Muurien (17) argued that education should also directly lower the marginal cost of holding the health capital by decreasing the deterioration rate $\delta_{t}$.

\section{Discussion}

The Grossman model of demand for health is built upon the Mushkin paradigm (14) - with health defined as a part of human capital, which can provide benefits to an individual - and the household production theory (11). The model maximises an individual's intertemporal utility and postulates that in equilibrium, the marginal benefits of health equal the marginal costs of health capital, where the former are the sum of marginal utility from health (consumption benefit) and marginal income from health (investment benefit), and the latter are the sum of marginal cost of medical care, interest rate and rate of depreciation. This means, that the decision on health investment depends fundamentally on this equilibrium and - within the realm of complete certainty - enables an individual to choose the optimal span of their life. Therefore, in other words, each death appears to be a form of suicide.

The crucial contribution of the Grossman model is in providing a theoretical framework, which emphasises in the author's own words, firstly, 'the difference between health as an output and medical care as one of many inputs in the production of health' (10) and secondly, 'the equally important difference between health capital and other forms of human capital' (10). Conceptually, the model also 
makes an important advancement in recognising that 'the value of medical care is the value of health it produces' (31). This conclusion is particularly important in the light of a well-known skewed distribution of medical care costs, where a minority of the population (20\%) accounts for the majority of costs (80\%) (32).

Among the most stringent assumptions of the model is its inability to deal with uncertainty, which is one of the fundamental hallmarks of the consumption and investment motives related to health. Accordingly, McGuire et al. (15) emphasises that one needs to distinguish between the 'risk - where individuals are able to attach probabilities to events - and uncertainty - where individuals are unable to do this'. In case of such an uncertainty, it is questionable whether intertemporal 'trading' of health as promoted by the Grossman model is possible at all (15). The model makes an additional major assumption of an individual having perfect information in order to maximise their utility. Although such assumptions are necessary, they should also be flexible enough to provide the model with some predictive power.

Empirical testing of the model has proven to be difficult due to the unobservability of some variables. Consequently, instead of structural formulation of the demand for health, Grossman (8) and later researchers had to resort to the reducedform estimates; to make the problem tractable they needed to make a choice between consumption and investment sub-models in spite of the fact that an individual demands health with a goal to capture both types of benefits. It has also been noted that in order to test the model properly, panel data following individuals over time would be required (9). Therefore, it is not surprising that some empirical estimates differed from the predictions of the Grossman model, most notable being the relationship between the health status and demand for medical care. The structural equation for demand for health shows that health status is positively correlated with the demand for medical services, which directly follows from the model's assertion that medical care is purchased to ensure the steady 'flow' of healthy days. In contradistinction, empirical results yielded the negative correlation $(33,34)$ - as it would be intuitively expected. One may argue that the divergence between the model's predictions and empirical results may be due to the model's theoretical assumption that health care benefits are 'realised steadily and constantly over time by the consumer' (15), which is clearly, among others, not the case in life-threatening conditions. In this context, it is worthwhile to recall some of the fundamental reasons of market failure in health care, such as simultaneous consumption and production of medical care and the fact that medical care has a heterogeneous character (15). One may thus assert that the role of medical care in the gross investment function is markedly simplified in the Grossman model.

Overall, the Grossman model provided conceptual grounds to show that medical care is only one among many inputs into the health status of an individual and the population, and this conclusion has been widely corroborated by epidemiological 
and clinical studies; this contribution by the model has even been highly valuable to the field of introductory health economics (21). Analytically, however, the model's performance still has to be confirmed. While the model has remained influential during the past 40 years, it has also been criticised by a number of researchers. For example Zweifel et al. (13), somewhat open-endedly concluded that 'the final verdict on the Grossman model is not returned yet' and McGuire et al. (15) remarked that the model 'remains restrictive and underdeveloped'. Even by acknowledging all the shortcomings of the model, Grossman still markedly advanced the understanding of an individual's motives for investment into health and stimulated research in a highly pertinent field; he alluded to these points with appropriate humour in one of his lectures: 'It's better to be the first or one of the first even if you're wrong (especially if you pick interesting problems to work on)' (35).

\section{Conclusion points}

The Grossman model is important not only in emphasising the distinction between demand for health and demand for healthcare, but also in demonstrating that health is both an investment and a consumption commodity. While the analytical nature of the model presents its strength, analytics also comes with the price of assumptions. When considering demand for health, assumptions of certainty and perfect information simply do not hold, and an individual remains faced with the impossible task of maximising their utility function when left to their own devices in the market. Some may argue that these assumptions arise from the quantitative nature of the model, which clashes with - to a large extent - the qualitative nature of health (36). In some ways, the shortcomings of the Grossman model illustrate quite well the complexity in understanding, and especially modelling the three fundamental demands in health economics: demand for health, demand for healthcare, and demand for health insurance.

An obvious extension of this overview is to cover the model's predictions, and discuss functional and reduced forms of the governing equations and empirical analyses of the model (e.g. 8, 16, 34, 37), where the observability of some of the model's variables remains one of the unsolved challenges.

\section{References}

1. Constitution of the World Health Organization. Basic Documents, Forty-fifth ed. Geneva: World Health Organization, 2006. Available 20. 12. 2011 on: http:// www.who.int/governance/eb/who_constitution_en.pdf.

2. The World Health Report 2000: health systems - improving performance. Geneva: World Health Organization, 2000. 
3. A conceptual framework for action on the social determinants of health. Geneva: World Health Organization, 2010.

4. Rogers RG, Hackenberg R. Extending epidemiologic transition theory: a new stage. Soc Biol 1987; 34(3/4): 234-43.

5. Yusuf S, Reddy S, Ôunpuu S, Anand S. Global burden of cardiovascular disease. Part I: general considerations, the epidemiologic transition, risk factors, and impact of urbanization. Circulation 2001; 104: 2746-53.

6. Gaziano TA. Cardiovascular disease in the developing world and its cost-effective management. Cardiol Rounds 2005; 9(2): 1-6.

7. Casselli G, Mesle F, Vallin J. Epidemiologic transition theory exceptions. Genus: Journal of Population Sciences 2002; 9: 9-51.

8. Grossman M. The demand for health: a theoretical and empirical investigation. New York: National Bureau of Economic Research, 1972.

9. Grossman M. On the concept of health capital and the demand for health. J Polit Econ 1972; 80(2): 223-55.

10. Grossman M. The human capital model. In: Culyer AJ, Newhouse JP, editors. Handbook of health economics. Vol. 1A. Amsterdam, Elsevier, 2000: 347-408.

11. Becker G. A theory of the allocation of time. Econ J 1965; 75(299): 493-517.

12. Zweifel P, Breyer F. Health economics. New York: Oxford University Press, 1997.

13. Zweifel P, Breyer F, Kifmann M. Health economics. 2nd ed. Dordrecht, New York: Springer, 2009.

14. Mushkin SJ. Health as an investment. J Polit Econ 1962; 70: S129-S157.

15. McGuire A, Henderson J, Mooney G. The economics of health care: an introductory text. London: Routledge, 1988.

16. Wagstaff $A$. The demand for health: an empirical reformulation of the Grossman model. Health Econ 1993; 2(2):189-98.

17. Muurien J-M. Demand for health: a generalized Grossman model. J Health Econ 1982; 1:5-28.

18. Case AC, Deaton A. Broken down by work and sex: how our health declines. Cambridge: National Bureau of Economic Research, 2003.

19. Dowie J. The portfolio approach to health behaviour. Soc Sci Med 1975; 9(11/12): 619-31.

20. Liljas B. The demand for health with uncertainty and insurance. J Health Econ 1988; 17(2): 153-70.

21. Folland S, Goodman AC, Stano M. The economics of health and health care (6th ed.). Upper Saddle River: Pearson Prentice Hall, 2010.

22. Ehrlich I, Chuma H. A model of the demand for longevity and the value of life extension. J Polit Econ 1990; 98(4): 761-82.

23. Usher D. Comments on "The correlation between health and schooling". In: Terleckyj NE, editor. Household Production and Consumption. New York: National Bureau of Econometric Research, 1975.

24. Halliday $\mathrm{TJ}$, He $\mathrm{H}$, Zhang $\mathrm{H}$. Health investment over the life-cycle. Working Papers 200910. Honolulu: University of Hawaii at Manoa, Department of Economics, 2009.

25. Cropper ML. Health, investment in health and occupational choice. J Polit Econ 1977; 85(6):1273-94. 
26. Muurien J-M, Le Grand J. The economic analysis of inequalities in health. Soc Sci Med 1985; 20(10): 1029-35.

27. Erbsland $M$, Ried $W$, Ulrich V. Health, health care, and the environment: econometric evidence from German micro data. Health Econ 1995; 4(3):169-82.

28. Leonard D, Van Long N. Optimal control theory static optimization in economics. Cambridge: Cambridge University Press, 1996.

29. Jacobson L. The family as producer of health - an extended Grossman model. J Health Econ 2000; 19(5): 611-37.

30. Bolin K, Jacobson L, Lindgren B. The family as the health producer - when spouses are Nash-bargainers. J Health Econ 2001: 20(3): 349-62.

31. Kohn LJ. A dynamic demand for medical care. PhD Thesis. Newark, NJ: Rutgers The State University of New Jersey, 2009.

32. Kaiser Family Foundation. Trends in health care costs and spending. 2007. Available 20. 12. 2011 on: http://www.kff.org/insurance/upload/7692.pdf.

33. Leu R, Gerfin M. Die Nachfrage nach Gesundheit - Ein empirischer Test des Grossman-Modells. In: Gäfgen G, editor. Informations- und Planungsprobleme in offentlichen Aufgabenbereichen. Frankfurt: Peter Lang, 1992: 1-90.

34. Wagstaff $A$. The demand for health: some new empirical evidence. J Health Econ 1986; 5(3):195-233.

35. Grossman M. It's better to be the first or one of the first even if you're wrong (especially if you pick interesting problems to work on). Seminar at the City University of New York, New York City, September 21, 2010. Available 20. 12. 2011 on: http://www.google.si/url?sa=t\&rct=j\&q=it\%E2\%80\%99s\%20better\%20 to 20 be $\% 20$ the 20 first\%20or\%20one\%20of\%20grossman\&source=web\&c $\mathrm{d}=1 \&$ ved $=0$ CB8QFjAA\& url=http\%3A\%2F\%2Fweb.gc.cuny.edu\%2Feconomics \%2FSeminarPapers\%2FFall\%25202010\%2FGC\%2520Seminar\%25209-21-10. ppt\&ei=Ug0fT-ayBMOq2gWt-8j6Dg\&usg=AFQjCNHkF_r3D09tgsy0ul00j6_ zsBFbLQ\&sig2=IYWme9bq-h0_v8OKOUF4uA.

36. Jiang $X$. An internal critique of neoclasical theory of health care consumption: a path towards a better theoretical alternative. Boston: New School for Social Research, University of Massachussets, 2008.

37. Nocera S, Zweifel P. The demand for health: an empirical test of the Grossman model using panel data. Dev Health Econ Pub Policy 1998; 6:35-49. 